\title{
Tajemnice narracji pierwszoosobowej czyli periplus w Dziejach Apostolskich
}

Narracja pierwszoosobowa w Dziejach Apostolskich od dawna budzi zainteresowanie i nieufność, ponieważ nie wiadomo, w jakich kategoriach ją postrzegać. Tekst ten jest próbą potraktowania pierwszoosobowych fragmentów jako elementów świadomie zastosowanej przez autora konwencji stylistycznej i gatunkowej.

Najpierw podane zostaną miejsca, w których spotkać można formy 1 os. pl i najpopularniejsze teorie tłumaczące obecność i funkcje tych form w toku narracji trzecioosobowej. Przy założeniu, że są to funkcje literackie, przeprowadzona zostanie segmentacja tekstu oparta na kryteriach literackich, a nie gramatycznych. Pozwoli to wygenerować pewien schemat fabularny typowy nie tylko Dziejów Apostolskich, lecz zauważalny też w utworach należących do klasycznej literatury grecko-rzymskiej. Podobieństwo schematu fabularnego oznacza zazwyczaj pokrewieństwo gatunków, można więc będzie passusy zawierające narrację pierwszoosobową zakwalifikować do odpowiedniego gatunku literackiego. Przykłady tekstów reprezentujących ten gatunek pomogą ustalić, czy wykładniki gatunku ograniczają się do schematu fabularnego i tematyki, czy obejmują też gramatykę i zjawisko zmian narracji z pierwszo- na trzecioosobową, a jeśli tak - to będzie można spróbować określić, jakie funkcje pełni w Dziejach Apostolskich narracja pierwszoosobowa, czy została zastosowana zgodnie bądź niezgodnie z konwencją gatunkową i praktyką literacką końca I w. n.e.

W tekście Dziejów Apostolskich od dawna zwracały uwagę fragmenty pisane w 1 os. pl., zwane powszechnie w biblistyce Wir-Berichte lub Wir-Passagen ${ }^{1}$. \footnotetext{
passim.

${ }^{1}$ Por. J. Wehnert, Die Wir-Passagen in der Apostelgeschichte (GTA 40), Göttingen 1989 ,
} 
Fragmenty te występują w drugiej części dzieła, poświęconej działalności apostoła Pawła. Zazwyczaj ich limitacja podporządkowana jest kryteriom gramatycznym: granice passusu wyznacza pierwsze i ostatnie pojawienie się 1 os. pl., czy to w formie czasownikowej, czy rzeczownikowej (zaimkowej), stąd większość opracowań jako Wir-Berichte podaje następujące sekwencje:

1. Dz 16,10-17;

2. Dz 20,5-15;

3. Dz 21,1-18;

4. Dz 27,1-28,16.

Co prawda w Kodeksie Bezy (D) narracja pierwszoosobowa pojawia się już w 11,28 (zamiast Jeden z nich, imieniem Agabus, powstawszy oznajmił

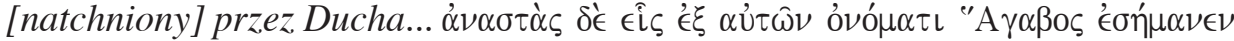

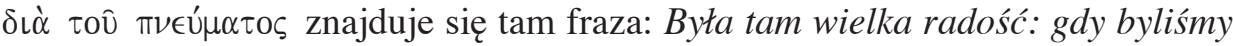

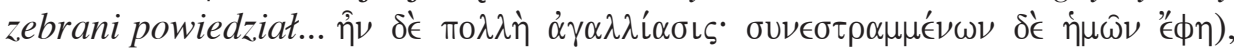
ale jest to wersja wtórna, mało wiarygodna, zawiera genetivus absolutus, poprawkę charakterystyczną dla zachodniej recenzji tekstu. Poza tym, jak można się będzie przekonać, pojawienie się już w tym miejscu 1 os. pl. nie znajduje uzasadnienia ani w treści, ani w gatunku literackim. Forma 1 os. została zapewne wprowadzona przez kopistę, aby zaznaczyć, że autor/narrator Dziejów związany jest z Antiochią.

Włączenie w narrację trzecioosobową narracji pierwszoosobowej było różnie tłumaczone. Już od starożytności największą popularność zyskało przekonanie, że Wir-Berichte jest świadectwem osobistego doświadczenia autora, który brał udział w opisywanych wydarzeniach ${ }^{2}$. Panowało powszechne przeświadczenie, że autorem Dziejów, podobnie jak i jednej z ewangelii synoptycznych, jest Łukasz, towarzysz Pawła, wymieniany w Flm 24; 2 Tm 4,11 i Kol 4,14. Pisze o tym Euzebiusz w Historii Kościelnej: „Paweł miał bardzo wielu współpracowników [....] Otóż większa ich część jemu właśnie zawdzięcza pamięć niewygasłą, bo niepożyte o nich w swych listach złożył świadectwo. Zresztą i Łukasz w swych Dziejach wylicza uczniów jego i przytacza ich imiona [...]. Łukasz, który był rodem z Antiochii, z zawodu lekarzem, a stale towarzyszył Pawłowi i z innymi apostołami się nie tylko przejściowo spotykał, złożył dowód, że się od nich nauczył leczenia dusz, bo pozostawił nam dwie przez Boga natchnione księgi. Jedną z nich jest Ewangelia [...]. Drugą księgą są Dzieje Apostolskie, które ułożył już nie z tego, co słyszał, ale z tego, co na własne oczy widział" (Hist. eccl. III,4,1-6). Tymczasem ani Dzieje, ani Ewangelia nie wspominają o Łukaszu, a 2 Tm i Kol uważane są za pisma deuteropaulińskie. Bezpieczniej jest więc

${ }^{2}$ J. Czerski, Księgi narracyjne Nowego Testamentu. Wprowadzenie historyczno-literackie i teologiczne, Opole 2003, 293. 
mówić o autorze Dziejów (i Ewangelii, bo oba teksty wyszły najprawdopodobniej spod ręki tego samego pisarza). Współczesne literaturoznawcze rozróżnienie pomiędzy autorem zewnętrznym i wewnętrznym pozwala Łukasza uznać za autora zewnętrznego, autor wewnętrzny, jako podmiot czynności tekstotwórczych, pozostaje anonimowy, a wnioskować o nim samym i jego kompetencjach pisarskich można wyłącznie na podstawie tekstów. Z tekstów zaś wynika, że autorem wewnętrznym Dziejów jest chrześcijanin pochodzenia pogańskiego, żyjący w czasach poapostolskich, biegle posługujący się greką koine, wykazujący dobrą znajomość kultury i literatury hellenistycznej ${ }^{3}$.

To właśnie ów autor wewnętrzny włączył do tekstu fragmenty z narracją pierwszoosobową. Czy zrobił tak dlatego, aby utożsamić się z narratorem i uwiarygodnić swoją relację jako pochodzącą od naocznego świadka? Czy też przydarzył mu się „błąd w sztuce” i do relacji o dziejach Pawła włączył nieprzeredagowany tekst źródłowy, pochodzący rzeczywiście od któregoś z towarzyszy apostoła narodów? Przeciw tej drugiej hipotezie przemawia podobieństwo, a nawet jedność stylu fragmentów narracji trzecio- i pierwszoosobowej. Dziwna wydaje się unifikacja stylistyczna materiału pochodzącego od naocznego świadka z resztą Dziejów, a pozostawienie tylko tej pierwszej osoby. Zazwyczaj tę zagadkę kwituje się stwierdzeniem, że pozostaje ona nierozwiązana ${ }^{4}$.

Wielu biblistów zwraca uwagę, że Wir-Berichte pojawia się we fragmentach opisujących podróże morskie ${ }^{5}$. Część uważa w związku z tym, że przekaz ten stanowi rodzaj dziennika podróży ${ }^{6}$, inni z kolei rozszerzają ów dziennik podróży także na teksty znajdujące się poza narracją pierwszoosobową (Dz 16,6-8. 11-12a; 17,1.10-11.15.17.34; 18,1-3.7-8.11.18-19.21-23; 19,1.9-10; 20,1-6.13$15 ; 21,1-4.7-9.15-16)$, ale przyznają, że Wir-Berichte mogą być częścią tego dziennika lub zostały do niego włączone przez autora wewnętrznego Dziejów Apostolskich ${ }^{7}$. Interpretacje te, biorące pod uwagę tematykę i specyficzny styl Wir-Passagen, zwracają się w kierunku prób wyjaśnienia zagadki z pomocą odniesień do gatunków literatury greckiej i rzymskiej. Oznacza to, że enigmatyczne Wir-Berichte mogą mieć charakter czysto literacki ${ }^{8}$.

${ }^{3}$ A. Läpple, Od egzegezy do katechezy, t. 2: Nowy Testament, Warszawa 1986, 431-432; J. Czerski, Księgi narracyjne, 302.

4 W. Rakocy, „Będziecie moimi świadkami...” (Dz1,8) (Dzieje Apostolskie), w: Dzieje Apostolskie, Listy św. Pawta (WMWKB 9), red. J. Frankowski - S. Mędala, Warszawa 1997, 18; H. Conzelmann, Die Apostelgeschichte erklärt, Tübingen 1972, 6.

${ }^{5}$ J. Czerski, Księgi narracyjne, 292; W. Rakocy, dz. cyt., 18.

${ }^{6}$ G. Schneider, Die Apostelgeschichte, t. 1, Freiburg - Basel - Wien 1980, 91.

${ }^{7}$ Tamże.

${ }^{8}$ J. Gnilka, Paweł z Tarsu, Kraków 2001, 23; J. Zmijewski, Die Apostelgeschichte, Regensburg 1994, 13-14. 
Pewien problem polega na tym, że segmentacja tekstu według kryteriów gramatycznych nie musi pokrywać się z delimitacją wedle kryteriów literackich. Zanim zaproponowany zostanie literacki podział tekstu, warto przyjrzeć się, co łączy wszystkie fragmenty zawierające narrację pierwszoosobową.

Przede wszystkim w oczy rzuca się podobny schemat fabularny ${ }^{9}$, który obejmuje następujące elementy:

a) rozpoczęcie podróży morskiej;

b) trasa podróży;

c) dotarcie do lądu;

d) pobyt na lądzie i spotkania z tubylcami;

e) opuszczenie miejsca pobytu.

Najbardziej charakterystycznym motywem, który pojawia się na wszystkich etapach podróży, jest motyw religijny. Bóg nie tylko inicjuje podróż: Staraliśmy się zaraz wyruszyć do Macedonii, wnioskując, że nas Bóg powołat, aby zwiastować im dobrq nowine $(16,10)$, ale też czuwa nad podróżnikami, kieruje ich losami, prowadzi w konkretne miejsca, zsyła zarówno przeciwności, jak i ratunek. Przeświadczenie o realizacji woli Bożej pozwala Pawłowi podtrzymać wiarę w ocalenie wśród współtowarzyszy podróży w czasie sztormu: Albowiem tej nocy staną przy mnie anioł tego Boga, do którego należe i któremu cześć oddaję, i rzekt: „Nie bój się Pawle; przed cesarzem stanqć musisz i oto darowat ci Bóg wszystkich, którzy z tobq płynq" (27,23-24); Bqudźcie dobrej myśli, mężowie. Ufam bowiem Bogu [...]. Wzią chleb, podziękowat Bogu wobec wszystkich, łamat i zacząt jeść. A wszyscy nabrawszy otuchy, równiez się posilili $(28,25.35-36)$ i w czasie uwięzienia w Filippi: A około północy Paweł i Sylas modlili się i śpiewem wielbili Boga $(16,25)$, prorocy przemawiający z natchnienia Ducha Świętego zdradzają Boże plany wobec Pawła i przestrzegają przed niebezpieczeństwem: A niektórzy za sprawa Ducha mówili Pawłowi, żeby nie szedt do Jerozolimy $(21,4) ;$ Nadszedt z Judei pewien prorok imieniem Agabus i przyszedtszy do nas, wziąt sobie pas Pawła, zwiqzat sobie nogi i ręce i rzekt: „To mówi Duch Święty: Męża, do którego ten pas należy, tak oto zwiqż $\dot{Z} y d z i$ w Jerozolimie $i$ wydadzq $w$ ręce pogan $(21,10-11)$. Narrator wspomina o modlitwach i obrzędach, w których bohaterowie uczestniczą i/lub je inicjują: A gdy szliśmy na modlitwe $(16,16)$; W dzień szabatu wyszliśmy za bramę nad rzekę, gdzie, jak squdziliśmy, odbywaty się modlitwy (16,13); A pierwszego dnia po sabacie, gdy zebraliśmy się na łamanie chleba [...]. [Paweł] wróciwszy na górę tamat chleb i spożywat i mówił aż do świtu (20,7.11); A padtszy na kolana na wybrzeżu, modliliśmy się

\footnotetext{
${ }^{9}$ Przez schemat fabularny rozumie się zwykle najważniejsze wydarzenia dotyczące głównej postaci/bohatera; jest on mniej rozbudowany niż tzw. linia fabularna obejmująca wszystkie wątki i motywy dotyczące głównej postaci/bohatera.
} 
(21,5); Gdy Pawet ich ujrzat, podzięował Bogu i nabrat otuchy $(28,15)$; Padt na kolana wraz z nimi wszystkimi i modlit się $(20,36)$.

W schemat fabularny wpisują się też różne inne motywy oraz wątki, bardziej lub mniej rozbudowane. I tak, rozpoczęciu podróży może towarzyszyć określenie jej celu: Staraliśmy się zaraz wyruszyć do Macedonii [...] aby zwiastować im dobrq nowine $(16,10)$.

Obok wyliczenia miejsc, które podróżnicy mijali lub do których dotarli, często spotyka się komentarze przybliżające odbiorcom/czytelnikom te miejsca: [zdqżaliśmy do] Filippi, które jest przodującym miastem okręgu macedońskiego i kolonia rzymskq $(16,11)$; dobiliśmy do pewnego miejsca, które zwano Piękne Przystanie, w pobliżu miasta Lasea $(27,8)$; większość uradziła, aby [...] dostać się jakoś do Feniksu, przystani na Krecie, otwartej na południowo-zachodniq i północno-zachodniq stronę $(27,12)$. Pojawiają się też informacje dotyczące odległości pomiędzy poszczególnymi miejscami oraz czas trwania kolejnych etapów podróży: My zaś odpłynęliśmy z Filippi [...] i w pięć dni przybyliśmy do nich do Troady (20,6); Odpłynq̨wszy stamtąd [z Mityleny], dotarliśmy następnego dnia na wysokość Chios, na drugi dzień dotarliśmy do Samos, następnego zaś dnia przybyliśmy do Miletu - 20,15; Przybyliśmy do Kos, nazajutrz zaś na Rodos (21,1); Przez wiele dni płynęliśmy wolno [z Miry] i dotarliśmy z trudem na wysokość Knidos (27,7); Dotarliśmy do Regium, a gdy po upływie jednego dnia powiał wiatr południowy, przybyliśmy następnego dnia do Puetoli $(28,13)$. Najbardziej rozbudowane opisy poszczególnych etapów podróży, łącznie z detalami dotyczącymi pogody, wyposażenia statku, rozmów i działań załogi, ukształtowania linii brzegowej, znajdują się w rozdziałach 27 i 28. Narrację charakteryzuje tu ogromny, umiejętnie dawkowany dramatyzm, pojawia się stopniowo i konsekwentnie rozwijany motyw zmagania z żywiołem morskim (27,4.7-8.9.13-20.27-32), katastrofy statku (27,39-41) i ocalenia rozbitków $(27,43-28,1)$.

Pobyt na lądzie mógł być planowany lub nie (jak w przypadku pobytu na Malcie). Jeśli nie wydarzyło się nic znaczącego, narrator nie poświęca temu epizodowi uwagi, poprzestając tylko na podaniu portu, do którego zawinęli podróżni, i/lub określenia, ile czasu tam spędzili, a takie wyliczenie można zaliczyć do opisu etapów podróży: Zdqżaliśmy do Samotraki, a nazajutrz do Neapolu (16,11); por. 20,13-16; A Przypłynqqwszy do Syrakuz, pozostaliśmy tam trzy dni $(28,12)$. Jeśli jednak tubylcy odnosili się do podróżnych szczególnie przyjaźnie lub szczególnie wrogo - fakt ten zostaje odnotowany, a pobyt opisany mniej lub bardziej szczegółowo: 16,12-18; 20,6-12; 21,4-6.7.8-15; 27,3; 28,1-10.14.15. Zasadniczym elementem każdego pobytu jest zwiastowanie. Narrator albo tylko o nim napomyka, jak w 16,14: Przysłuchiwała się temu pewne bogobojna niewiasta imieniem Lidia [...], której Pan otworzyt 
serce, tak iż się skłaniała ku temu, co Paweł mówił, czy w 20,7: Paweł [...] przemawiat do nich i przeciagat mowe aż do północy, albo przytacza w całości lub fragmentach, jak w 16,31-32: Uwierz w Pana Jezusa, a będziesz zbawiony ty i twój dom. I głosili Słowo Pańskie lub 21,13. W dłuższych relacjach o pobycie Pawła i jego towarzyszy w Filippi (16,12-18), Troadzie $(20,6-12)$ i na Malcie (28,1-10) zwracają uwagę cuda, jakich Paweł dokonał - egzorcyzmy na wieszczącej dziewczynie (16,16-18), przywrócenie do życia Eutychusa (20,9-12), brak reakcji na ukąszenie żmii (28,3-6), uzdrowienie ojca naczelnika Malty, Publiusza i innych chorych na wyspie $(28,8-9)$. Cuda spotykały się zazwyczaj z podziwem i wdzięcznością tubylczej ludności $(20,12 ; 28,10)$, która gotowa była nawet uznać Pawła za jednego z bogów $(28,8)$, jednak zdarzało się, że działalność apostoła zakłócała dotychczasowe układy społeczne i maleficjenci - jak ci w Filippi, którzy zostali pozbawieni źródła dochodu - dążyli do ukarania przybyszy i skłonienia ich do opuszczenia miasta (16,19-23.38-39).

W tym miejscu pojawia się wspomniany wyżej problem segmentacji tekstu: czy represje, jakie spotkały Pawła i Sylasa w Filippi, cudowne uwolnienie z więzienia, nawrócenie strażnika (16,19-40), należy zaliczyć do narracji pierwszoosobowej, czy też nie? Z jednej strony, epizody te łączą się bezpośrednio z Wir-Berichte, stanowią bowiem ciąg dalszy opisu pobytu apostołów w Filippi, z drugiej strony jednak relacja utrzymana jest w 3 os. Jeśli rozpatrywać ten fragment w jakichkolwiek kategoriach literackich, należy uznać, że całość stanowi opowiadanie rozpoczynające się przybyciem do Filippi w Macedonii $(16,12)$, a zakończone opuszczeniem miasta (16,39-40), ponieważ zmiana scenerii, miejsca akcji stanowi zwykle jeden $\mathrm{z}$ najbardziej popularnych (i naturalnych) sposobów podziału tekstu. Wykładnikami delimitacji będą tu wyrażenia oznaczające podjęcie podróży i przybycie/przypłynięcie do Macedonii oraz opuszczenie/odejście z Filippi, niezależnie od tego, w jakiej formie gramatycznej

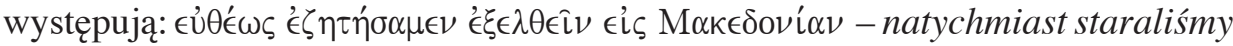

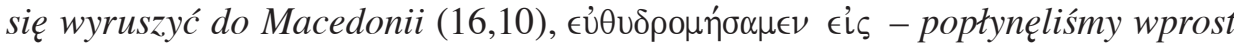

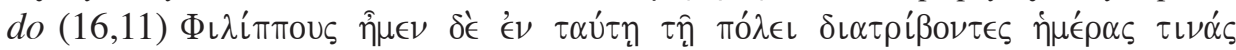

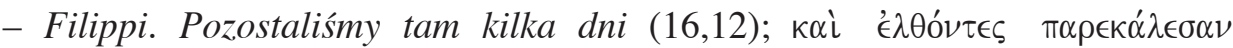

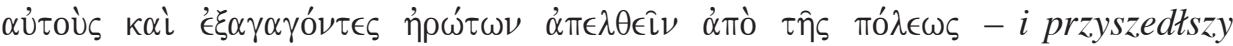
wezwali ich, $i$ wyprowadziwszy prosili, aby odeszli z miasta. $(16,39) \kappa \alpha \grave{\iota}{ }^{\epsilon} \xi \hat{\eta} \lambda \theta \alpha \nu-$ i odeszli $(16,40)$. Widać, że w zdaniu inicjalnym i w zdaniu finalnym użyty został

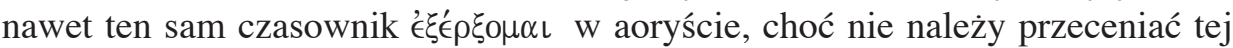
- prawdopodobnie przypadkowej - zbieżności.

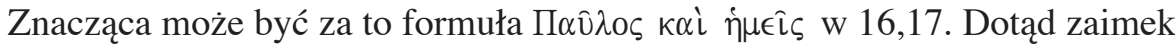
$\dot{\eta} \mu \in \hat{\imath} \varsigma$ obejmował Pawła i narratora. Narrator pierwszoosobowy relacjonował wydarzenia ,zwykłe”: spotkania z tubylcami, zwiastowanie, chrzty, nawet egzorcyzmy.Relacjonowałjez pozycjinarratora posiadającegopewną,,nadwiedzę”" 
w stosunku do odbiorcy tekstu - tzw. narratora czynnego (aktorial), ale nie z pozycji narratora wszechwiedzącego - tzw. autorytatywnego (auktorial); na to nie pozwala konwencja pierwszoosobowa. Tymczasem relacja o cudownym uwolnieniu Pawła i Sylasa z więzienia wymagała wprowadzenia narratora wszechwiedzącego, który znałby myśli i motywacje strażnika więziennego $(16,27)^{10}$, takim narratorem może być tylko narrator trzecioosobowy. Autor wewnętrzny dokonał zatem tej zamiany, zaznaczając ją rozdzieleniem „nas” i „Pawła”. O tym, co przydarzyło się Pawłowi, można było dzięki temu opowiedzieć bez „balastu” i ograniczeń narracji w pierwszej osobie. O innych przyczynach zmiany form narracji będzie mowa nieco dalej.

Rozszerzenie pierwszego fragmentu zawierającego Wir-Berichte aż do 16,40 wpisuje się $\mathrm{w}$ przedstawiony wyżej schemat fabularny obejmujący motyw opuszczenia przez bohaterów miejsca pobytu. Czasem motywowi temu towarzyszy opis pożegnania z tubylcami: Kiedy nasz pobyt [w Tyrze] sie skończyt, wyruszyliśmy i udaliśmy się $w$ drogę, a wszyscy wraz z żonami i dziećmi towarzyszyli nam aż za miasto, a padtszy na kolana na wybrzeżu, modliliśmy się i pożegnaliśmy wzajemnie. Potem wsiedliśmy na statek, a tamci wrócili do domu (21,5-6); Gdy mieliśmy odpłynać, zaopatrzyli nas w co potrzeba, a po trzech miesiqcach ruszyliśmy $w$ drogę na aleksandryjskim statku $(28,10-11)$. Wydaje się więc, że podobnie jak rozszerzono pierwszy passus z narracją pierwszoosobową, należy rozszerzyć również fragment drugi, który obejmowałby teraz: podróż z Filippi do Troady, wskrzeszenie Eutychusa w Troadzie (również opisane za pomocą narracji trzecioosobowej!), podróż do Assos, Mytyleny, Samos i Miletu, mowę Pawła w Milecie (20,18-35) i opuszczenie Miletu (20,37-38). W Milecie apostoł nie spotkał się co prawda z tubylcami, lecz ze starszymi wezwanymi z Efezu, ale w schemacie fabularnym pełnią oni tę samą rolę, co tubylcy przyjmujący podróżnych. Podkreśla to dodatkowo scena pożegnania: I wszyscy rzewnie płakali i rzucając się na szyje Pawłowi, całowali go, cierpiąc bardzo z powodu słowa, które powiedział, że już nigdy go nie zobaczq. I odprowadzili go na statek (20,37-38). Za wykładniki delimitacji relacji o pobycie w Milecie po-

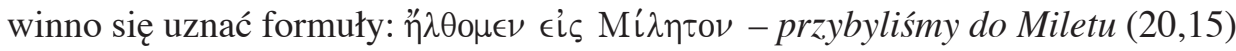

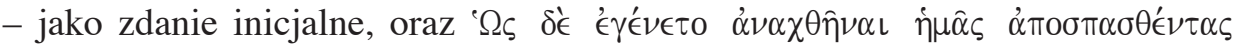

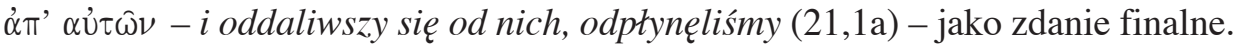
Druga narracja zawierająca Wir-Berichte byłaby zatem bezpośrednio połączona z trzecią, którą rozpoczyna opis podróży do Kos, Rodos, Patary, a następnie do Tyru (21,1b-6), Cezarei (21,7-14) i Jerozolimy (21,15-17). Czwarty fragment obejmowałby, jak dotychczas, Dz 27,1-28,16. Podobnie jak nie budzi większych

${ }^{10}$ Stwierdzenie z 16,14 - Pan otworzyt serce [Lidii], tak iż skłaniała się ku temu, co Paweł mówit - jest wyrazem wiary narratora, nie wynika z jego wszechwiedzy. 
wątpliwości przemowa Pawła na statku w 28,21b-26, tak samo nie powinna budzić wątpliwości jego osobista mowa w Milecie - 20,18b-35.

Kierując się przytoczonym wcześniej schematem fabularnym, można inaczej podzielić tekst - tak, aby łatwiej było dostrzec wszystkie punkty schematu, a tym samym literacki charakter i charakterystyczną kompozycję narracji opowiadających o podróżach morskich i zawierających Wir-Berichte:

1. Dz $16,10-40$

a) rozpoczęcie podróży - 16,10-11a;

b) trasa podróży - 16,11b-12a;

c) dotarcie do lądu - 16,12b;

d) pobyt i spotkania z tubylcami - 16,13-38;

e) opuszczenie miejsca pobytu - 16,39-40;

2. Dz 20,6-13

a) rozpoczęcie podróży - 20,6a;

b) trasa podróży - 20,6b-c;

c) dotarcie do lądu - 20,6c;

d) pobyt i spotkania z tubylcami - 20,7-12;

e) opuszczenie miejsca pobytu - 20,13;

3. Dz 20,14-21,1a

a) rozpoczęcie podróży - 20,14a;

b) trasa podróży - 20,14b-15;

c) dotarcie do lądu - 20,15c;

d) pobyt i spotkania z tubylcami - 20,17-36;

e) opuszczenie miejsca pobytu - 20,37-21,1a;

4. Dz 21,1a-7a

a) rozpoczęcie podróży - 21,1a

b) trasa podróży - 21,1b-3c;

c) dotarcie do lądu - 21,3c-d;

d) pobyt i spotkania z tubylcami - 21,4 ;

e) opuszczenie miejsca pobytu - 21,5-7a;

5. Dz 21,7a-15

a) rozpoczęcie podróży $-21,7 a$;

b) trasa podróży - 21,7a-8a;

c) dotarcie do lądu - 21,8a;

d) pobyt i spotkania z tubylcami $-21,8 b-15 a$;

e) opuszczenie miejsca pobytu $-21,15 b-c$;

6. Dz 21,15c-17

a) rozpoczęcie podróży $-21,15 \mathrm{c}$;

b) trasa podróży - 21,16;

c) dotarcie do lądu/celu - 21,17a;

d) pobyt i spotkania z tubylcami $-21,17 b$; 
7. Dz 27,1-4a
a) rozpoczęcie podróży - 27,1-2;
b) trasa podróży - 27,1a.2a;
c) dotarcie do lądu - 27,3a;
d) pobyt i spotkania z tubylcami - 27,3c-d;
e) opuszczenie miejsca pobytu $-27,4 a$;

8. Dz 27,4a-28,10
a) rozpoczęcie podróży - 27,4a;
b) trasa podróży - 27,4b-40;
c) dotarcie do lądu - 27,41-28,1;
d) pobyt i spotkania z tubylcami - 28,2-10a;
e) opuszczenie miejsca pobytu $-28,10 \mathrm{~b}-\mathrm{c}$;

9. Dz 28,11-16
a) rozpoczęcie podróży - 28,11;
b) trasa podróży - 28,12-14;
c) dotarcie do lądu - 28,14d;
d) pobyt i spotkania z tubylcami - 28,15-16.

Dopiero teraz łatwiej jest zauważyć dwie istotne rzeczy. Po pierwsze relacje o pobycie wśród tubylców w Dz 16,19-38; 20,7-12; 28,3-6 zawierają epizody tworzące rodzaj narracji intradiegetycznej w stosunku do opowiadania głównego - morskiej podróży. Wtedy krótka zmiana osoby w narracji przestaje dziwić - narrator epizodu intradiegetycznego musi się w jakiś sposób odróżniać od narratora głównego. A ponieważ nie zastosowano tu najprostszego poziomowania narracji, czyli przytoczenia czyjegoś opowiadania, najbardziej naturalnym, wręcz narzucającym się sposobem odróżnienia opowiadania głównego i opowiadania wtórnego jest przejście z narracji pierwszoosobowej do narracji trzecioosobowej.

Po drugie - dwie spośród relacji o podróży morskiej $(21,15 c-17 ; 28,11-16)$ pozostają otwarte, nie mają typowej formuły finalnej, zakończenia mówiącego o opuszczeniu miejsca pobytu. Przeciwnie, po spotkaniu z tubylcami bohaterowie ruszają w głąb lądu i docierają do miejsc coraz bardziej oddalonych od wybrzeża. Może też pojawić się dłuższe opowiadanie o tym, czego doświadczyli bohaterowie podczas podróży lądowej: 21,18-26,32. Dochodzi nie tylko do zmiany scenerii z morskiej na lądową, ale też zmiany gatunku literackiego, co autor wewnętrzny stara się zaznaczyć, zmieniając m.in. typ narracji - z narracji pierwszoosobowej na narrację trzecioosobową.

Należy więc głębiej zastanowić się, jaki gatunek literacki reprezentują fragmenty Dz zawierające Wir-Beriche. Pomocą może się tu okazać schemat narracyjny, ponieważ często podobieństwo schematów przekłada się na 
podobieństwo/pokrewieństwo gatunkowe tekstów. Sekwencja: rozpoczęcie podróży - trasa podróży - dotarcie do lądu - pobyt i spotkania z tubylcami - opuszczenie miejsca pobytu, do tego morska sceneria pojawia się w gatunku literatury

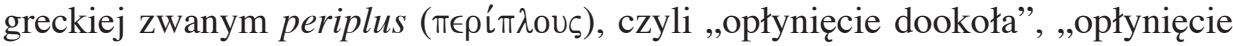
wzdłuż brzegów morza lub wyspy" "I. Jako cechy/motywy charakterystyczne gatunku wymieniane są: opisy wybrzeży przy rozpoczęciu podróży; czasowniki: sq̨siaduje, minęliśmy; wzmianki o ludziach/narodach zamieszkujących brzegi morza, nadmorskie miasta; opisy miast i portów. Często podawane są odległości (w stadiach) oraz czas trwania podróży (w dniach). Pojawiają się krótkie informacje na temat zjawisk meteorologicznych, wiatrów, rzek, podkreśla się możliwość lądowania, charakter portów i miejsc postoju. Wspomina się skały, przypływy i odpływy morza, podaje informacje o mieszkańcach i ewentualne przestrogi ${ }^{12}$. Jako przykład typowego periplus przytaczany jest zazwyczaj fragment Periplusa dookoła Europy, Azji Libii przypisywanego Skylaksowi z Kariandy (VI w. p.n.e.), choć powstałego prawdopodobnie dwa wieki później: „Najpierw Eleusis, gdzie znajduje się świątynia Demetry i murowana warownia (naprzeciw leży wyspa Salamina i port). Potem Pireus, mury i Ateny. Pireus zaś ma trzy porty. Potem znajduje się przylądek Sunion ze świątynią Posejdona. Jest też wiele innych portów w Attyce"13.

Nie da się też nie zauważyć podobieństw z wędrówkami Odyseusza ${ }^{14}$ i Eneasza. W Księdze IX Odysei główny bohater relacjonuje Alkinoosowi:

A więc słuchaj: opowiem powrót nieszczęśliwy

Spod Troi, jak mię trapił Zeus swoimi gniewy.

Z Ilionu ku Kikonom zagnan wieją wściekłą,

Zburzyłem Ismar, gród ich; [...]

Z ciężkim na duszy smutkiem płynęliśmy dalej [...],

Gdy wtem na nasze nawy przyszła sroga fala:

Pędził ją Borej, wolą wzburzon chmurowładną.

I mgły gęste wraz na ląd i na morze padną,

Z nieba noc się stoczyła, a nasze okręty,

Aż maszty się pokładły, tak mkną przez odmęty.

Wichr w żagle wpadłszy rwał je na troje, na czworo;

Lecz z obawy wywrotu zwijamy je skoro

I wiosłując z mozołem, dopychamy łodzie

${ }^{11}$ Słownik rodzajów i gatunków literackich, red. G. Gazda - S. Tynecka-Makowska, Kraków 2006, 524

12 Tamże.

${ }^{13}$ Tamże, 525.

${ }^{14}$ Związki Dz z dziełami Homera szeroko opisuje D. MacDonald, Does the New Testament Imitate Homer? Cases from the Acts of the Apostels, New Heven 2003, passim. 
Do brzegu, gdzie dwie doby na tej niepogodzie

Staliśmy, ciągłą pracą i smutkiem już zbici.

$\mathrm{W}$ dniu trzecim, gdy rumiana Eos nam zaświeci,

Dźwignąwszy maszty, żagiel zawiesiwszy biały

Siedzimy w nawach, które wiatr i sternik gnały,

A jam w powrót szczęśliwy nie tracił nadziei.

Lecz prąd morski płynących około Malei,

Toż Borej -jak nas schwycą, tak w przeciwną stronę

Od Kyterów odrzucą. Więc przez wody słone

Dni dziewięć wciąż pędzony wichry zajadłemi,

Aż w dziesiątym nareszcie dobiłem do ziemi

Lotofagów, co lotos jedzą [...].

Stamtąd-eśmy płynęli, płynęli wciąż smutni,

Aż do ziemi Kyklopów [...].

Przystań dobra, bez liny żeglarz się obchodzi,

Kotwicy nie zarzuca, nie cumuje łodzi,

Bo ta stoi bezpiecznie, aż póki żeglarzy

Potrzeba nie przynagli lub wiatr, co się darzy.

Wyż przystani jest źródło bijące z kamienia;

Przejrzyste jego wody gaj topól ocienia.

Tam lądujem [...].

Tego typu opowieść pojawia się też w następnych księgach eposu. Na przykład w Księdze XII można przeczytać:

Skoro okręt nasz prądy oceanu minął

I na bezkresny przestwór wód morskich wypłynął,

Pędzim ku wyspie Ajai, gdzie Eos się rodzi,

Gdzie mieszka z swym orszakiem i gdzie Helios wschodzi;

A stanąwszy u brzegu przy piaszczystej ławie,

Wysiadamy z okrętu, znużeni w przeprawie [...].

Wtem jutrznia zabłysła na niebie

Kirka mię pożegnawszy odeszła do siebie;

Ja na okręt zwołałem czeladź rozpierzchnioną,

Kazałem, by od brzegu liny odczepiono [...].

W burzach morskich i w przygód przeróżnych natłoku.

Wymknąwszy się z Charybdy i Skylli przesmyku,

Przybyliśmy do wyspy bożej, gdzie bez liku

Heliosowego bydła na łąkach się pasa;

[...] Zatem nie płynąc już dalej,

Zawinęliśmy w przystań wydrążoną nawą

Nie opodal wód słodkich, i drużyna żwawo

Wyskoczyła, wieczerzę na brzegu przyrządza [...], 
Nagle wiatr ustał, srogiej nie było już wiei.

Wsiadamy więc, sterujem na morze otwarte [...].

Tak dni dziewięć się tłukłem, aż dziesiątej nocy

Przybiłem do Ogygii przy boskiej pomocy,

Gdzie mieszka pięknowłosa Kalypso, bogini.

Gościnnie tam przyjęty, długom bawił przy niej ${ }^{15}$.

Ponieważ Eneida Wergiliusza wzorowana jest na dziele Homera, nic więc dziwnego, że i tam „morskie opowieści” mają podobną strukturę, szczególnie w księdze III, gdzie opisane zostały dzieje bohatera po jego ucieczce z Troi - podróże do Tracji, na Kretę, do Strofady, Akcjum, Epiru, a wreszcie na Sycylię i Drepanum.

Bardzo charakterystyczną cechą Odysei jest prowadzenie narracji w 1 os. sing. lub pl. (często zamiennie). Siostrzana, choć późniejsza o osiem stuleci, Eneida powtarza ten zabieg. Oczywiście wynika to przede wszystkim z tego, że narrator jest zarazem bohaterem utworu. Z drugiej jednak strony, może świadczyć o tym, że tradycja opowiadania o podróżach morskich w 1 os. sięga czasów Homera, a periplus obecny w Odysei stał się wzorcem gatunkowym dla późniejszych podobnych opowiadan, czy to epickich, czy lirycznych.

Nieprzypadkowo zapewne Alkajos (VII w. p.n.e.) używa 1 os. pl., opisując żeglugę (która jest w istocie alegorią państwa-okrętu zagrożonego nawałnicą) ${ }^{16}$ :

Znów taka fala, jak niegdyś napływa,

Czerpanie wody znów czeka nas znojne,

Gdy na nasz pokład zwalą się [bałwany][...].

Więc jak najszybciej umocnijmy burty,

Czas ku przystani podążyć bezpiecznej.

Niech nikt się trwodze niegodnej nie podda,

Przed nami wielkie i trudne zadanie ${ }^{17}$.

Podobnie postępuje Mimnermos (VII w. p.n.e.) w Smyrneidzie, utworze określanym jako dłuższa elegia historyczno-wojenna, obejmująca takie

15 Przekład L. Siemieńskiego, za: http://polonista.w.interia.pl/homer/odyseja.html (27.03.2008).

16 V.K. Robbins, By Land and by Sea: The We-Passages and Ancient Sea Voyages, w: Perspectives on Luke-Acts (Perspectives in Religious Studies, Special Studies Series 5), red. C.H. Talbert, Edinburgh 1978, 219.

${ }^{17}$ Przekład J. Danielewicza, w: J. Danielewicz, Liryka starożytnej Grecji, Warszawa - Poznań 1996, 201-202. 
epizody jak: zasiedlenie Kolofonu, opanowanie Smyrny, walka Smyrnejczyków z Gygesem ${ }^{18}$. Wydarzenia poprzedzające zdobycie Smyrny rozgrywają się na morzu, schemat fabularny i narracja pierwszoosobowa są aż nadto widoczne:

Kiedy i strome Pylos rzuciliśmy, miasto Neleusa, oto do Azji ponętnej nas okręty przywiodły.

Zasiedliliśmy miły Kolofon, bo byliśmy zbrojni w siłę przemożną, a pycha wówczas nas wiodła bolesna.

Stamtąd ruszyliśmy dalej i rzekę Asteeis przeszedłszy, zgodnie z bogów zamysłem wzięliśmy Smyrnę eolską ${ }^{19}$.

Ten typ narracji występuje też w utworach prozaicznych. Za najstarszy periplus tego rodzaju uchodzi Periplus Massiliensis z VI w. p.n.e., przypisywany Eutymenesowi z Marsylii, oraz zaginiony Periplus Skylasa z Kariandy, również z VI w. p.n.e. Zachował się za to Periplus Hannona z IV w., opisujący podróż wzdłuż wybrzeży zachodniej Afryki, przełożony w II w. p.n.e. na łacinę ${ }^{20}$.

Periplus mógł być utworem samodzielnym, ale mógł też stanowić komponent utworów o innych charakterze, tak jak to widać w Odysei. Nawiązania w literaturze greckiej do Homera nie są przypadkowe. Dzieła niewidomego aojdy postrzegano jako skarbiec motywów i wzorców strukturalnych dla późniejszej literatury, zwłaszcza dla antycznej noweli i powieści. Jak trafnie zauważa U. Wilamowitz-Moellendorf: [Odyseja] wprowadza nas w inny świat, a właściwie nawet w dwa światy - w świat fabularny greckich opowieści żeglarskich i w świat noweli ${ }^{21}$. Z czasem ukształtowały się dwa zasadnicze typy powieści antycznej: powieść idealizująca - przygodowa i/lub przygodowoawanturnicza, oraz powieść komiczno-realistyczna - „romans” opowiadający o rozdzieleniu kochanków i perypetiach prowadzących do ponownego połączenia pary $^{22}$. W powieści idealizującej periplus jest jednym $\mathrm{z}$ zasadniczych komponentów fabuły, w powieści komiczno-realistycznej pojawia się nieco rzadziej. O popularności periplusa może świadczyć wykorzystanie tego gatunku m.in. w Przygodach Chajreasa i Kalliroe Charitona (I lub II w.), w Leukippe $i$ Klejtofoncie Achilleusa (Achillesa) Tatiosa (II w.) czy w Opowieściach etiopskich Heliodora (III w.). Warto zaznaczyć, że dominantę w Leukippe... stanowi narracja pierwszoosobowa (,pamiętnik kochanka”), ale przerywają ją

\footnotetext{
${ }^{18}$ Tamże, 101.

${ }^{19}$ Przekład W. Appla, w: J. Danielewicz, Liryka starożytnej Grecji, 437.

${ }^{20}$ Słownik rodzajów i gatunków literackich, 525.

${ }^{21}$ U. Wilamowitz-Moellendorf, Die Heimkehr des Odysseus, Berlin 1927, 177, cyt. za: R. Turasiewicz, Grecka nowela antyczna, Wrocław 2005, xv.

${ }^{22}$ N. Holzberg, Powieść antyczna, Kraków 2003, 49.
} 
trzecioosobowe epizody, przypowieści, opisy itp.; w Opowieściach etiopskich poziomy i formy narracji są dużo bardziej skomplikowane.

Literatura tego typu była niezwykle ekspansywna od II w. p.n.e. do II/III w. n.e. A więc na czas, gdy powstały Dzieje Apostolskie (koniec I w.), przypada niemal apogeum jej popularności. Atrakcyjności dodawały jej różnego rodzaju ekskursy, informacje geograficzne, historyczne i mitologiczne, mowy itp. włączane do tekstu. Miejscami powieść antyczna przypominała nawet literaturę paranaukową. I odwrotnie - dzieła naukowe, zwłaszcza historiograficzne, uzupełniano nowelami, przypowieściami, anegdotami, tak że ich kształcący charakter ginął wśród elementów służących rozrywce. Dzięki eklektyzmowi gatunkowemu i tematycznemu, za którymi idzie eklektyzm stylistyczny, powieści i historiografia stanowią dla odbiorców niemal niewyczerpane źródło relacji intertekstualnych.

Przykładem synkretycznej pod wieloma względami narracji jest Prawdziwa historia Lukiana z Samostat (120-180). Lukian prowadzi z odbiorcami bardzo subtelną grę intertekstualną i międzygatunkową, „czyniąc tym samym opisywaną podróż metaliteracką wycieczką przez morze słów i tekstów"23, parodiując hellenistyczną retorykę i antyczną powieść awanturniczo-przygodową. Bohaterami swojego tekstu czyni grupę pięćdziesięciu Greków udających się w morską podróż w nieznane. Pierwszym etapem podróży jest wyspa z rzekami, w których zamiast wody płynie wino. Po opuszczeniu tej cudownej krainy, wędrowcy wypłynęli na morze, gdzie szalał sztorm, a wiatr był tak gwałtowny, że uniósł statek w powietrze. Następnym etapem wyprawy jest więc podróż powietrzna, w czasie której bohaterowie trafiają do różnych krain, m.in. na Księżyc zamieszkany wyłącznie przez mężczyzn (mężczyźni ci rodzą nawet dzieci, z tym że ciąża rozwija się w... łydkach), odwiedzają istoty zwane Drzewianami, biorą udział w wojnie mieszkańców Księżyca z mieszkańcami Słońca. Po jakimś czasie udaje im się wrócić na morze, aby niemal natychmiast trafić do wnętrza wieloryba, podobnie jak biblijny Jonasz. Udaje im się jednak wydostać, a po kolejnych przygodach docierają do Wysp Szczęśliwych. Nikt z odbiorców nie ma wątpliwości, że narrator wypowiadający się w 1 os. - zamiennie pl. i sing. - nie brał udziału w takiej podróży - ani morskiej, ani powietrznej. Przyjmują jednak taki sposób narracji jako pewną konwencję przewidzianą dla opowieści typu periplus. Historia prawdziwa jest bowiem niemal klasycznym przykładem periplusa z charakterystycznym dla niego schematem narracyjnym: „Po siedmiu dniach i tyluż nocach naszej podróży ujrzeliśmy ósmego dnia w przestworzach jakąś wielką ziemię [...]. Przybliżywszy się do niej, przybiliśmy naszym pojazdem i wyszliśmy na ląd [...]. Chcieliśmy jeszcze dalej posuwać

\footnotetext{
${ }^{23}$ Tamże, 29.
} 
się w głąb terenu, lecz natknęliśmy się na tzw. tutaj Koniosępów, którzy nas uwięzili ${ }^{24}[\ldots]$. Kiedy przybyliśsmy na Księżyc, spotkaliśsmy się z naszymi towarzyszami i z samym Endymionem. On chciał, abym został z nim i dołączył do jego kolonii. Obiecał mi nawet małżeństwo z jego własnym synem - kobiet bowiem nie ma w tej krainie - lecz nie dałem się przekonać. Prosiłem go, aby pozwolił mi odpłynąć. Kiedy spostrzegł, że nie zdoła mnie do tego nakłonić, wyprawił nas w podróż, ugościwszy przedtem przez siedem dni”25.

Nawiązania intertekstualne $i$ aluzje gatunkowe wydają się istotne w wyjaśnieniu „tajemnicy” Wir-Berichte w Dziejach Apostolskich. Nie ma powodu wątpić, że autor Dziejów jest Grekiem (choć nie musiał nosić imienia Łukasz i osobiście zetknąć się z Pawłem). Z prologu do Łk wiadomo, że przy tworzeniu tekstu korzystał z metodologii, jaką posługiwali się greccy historiografowie czerpiący z retoryki Izokratesa, a oddalający się od obiektywizmu i weryfikalności przedstawianych faktów postulowanych przez Tukidydesa. Dobra greka świadczy o tym, że otrzymał wykształcenie, aluzje do prądów filozoficznych i literackich każą przypuszczać, że znał dzieła klasycznej literatury greckiej i rzymskiej i rozróżniał gatunki literackie. Na retoryzację Dziejów wskazują liczne, starannie skomponowane mowy, pojawiające się również w periplusie (20,18-35; 28,21-26). Jeśli łączyć autora wewnętrznego z Antiochią, za czym opowiada się tradycja, to nawiązanie do dziedzictwa klasycznego staje się jeszcze wyraźniejsze, ponieważ zetknięcie się Greków małoazjatyckich z odmiennymi kulturami zmuszało ich do uświadomienia sobie własnej etnicznej więzi i odrębności kulturowej ${ }^{26}$. Poza tym wprowadzenie do narracji historiograficznej innego gatunku - tu periplusa, przypowieści, mowy - wynikało w dużej mierze stąd, że pisarz odpowiadał w ten sposób na oczekiwania, a czasem wręcz na wymogi społeczne. Odbiorcy literatury historiograficznej nie wyobrażali sobie zapewne utworu o charakterze narracyjnym, pozbawionego takich form opowiadania, które przez swoją dygresyjność, czasem nawet niezależność od głównej linii fabularnej, potęgowały zainteresowanie, ubarwiały tok narracji, a zarazem służyły celowi umoralniającemu ${ }^{27}$. Wydaje się więc, że fragmenty zawierające narrację pierwszoosobową są świadomie wprowadzonymi do tekstu nawiązaniami do literatury klasycznej, przede wszystkim do wzorcowego periplusa - Odysei Homera - oraz próbą uatrakcyjnienia utworu skierowanego do wybrednych zapewne odbiorców greckich. Często poprzez nawiązanie do Homera autor wewnętrzny chce nowy utwór uczynić bardziej

\footnotetext{
${ }^{24}$ Przekład R. Turasiewicza, w: R. Turasiewicz, Grecka nowela antyczna, 239-230.

${ }^{25}$ Przekład własny za: http://www.sacred-texts.com/cla/luc/true/tru01.htm (27.03.2008).

${ }^{26}$ Por. R. Turasiewicz, Grecka nowela antyczna, xxi.

${ }^{27}$ Por. tamże, xxiii-xxiv. xxx.
} 
wartościowym i „salonowym” w oczach odbiorców ${ }^{28}$. Z analizy Dziejów Apostolskich wynika, że implikowani odbiorcy mogli należeć do „salonowego" towarzystwa, z którego zapewne wywodził się również bezpośredni adresat ŁkDz - „dostojny Teofil” (Łk 1,3; Dz 1,1) ${ }^{29}$.

Analogiczne uwagi dotyczące gry intertekstualnej można zastosować do opowiadań trzecioosobowych wplecionych w narrację pierwszoosobową. Stanowią one inny gatunek literacki - coś w rodzaju Ezopowych przypowiastek, jak ta o ukąszeniu Pawła przez żmiję $(28,4-6)$, więc zaznaczenie zmiany gatunku zmianą osoby narracji wydaje się uzasadnione. Pominięcie tych opowieści nie ma większego wpływu na tok narracji całego utworu, choć niewątpliwie mają one znaczenie funkcjonalne, np. podkreślanie szczególnego wybrania apostoła, determinacji i skuteczności w głoszeniu ewangelii itp.

Podobna strategia została zastosowana w Satyrykach, czyli Opowieściach ze świata satyrów Petroniusza (27-66), tego samego, którego opisał Sienkiewicz w Quo vadis. Bohaterem, a zarazem narratorem tego utworu, zachowanego niestety fragmentarycznie, jest Enkolpius zakochany w chłopcu imieniem Giton. W skład tej historii, oprócz najbardziej znanej Uczty Trimalchiona, wchodzą przygody, jakie spotykają bohatera i jego wybranka podczas podróży morskiej. Na statku przebywa też poeta Eumolpus, który ,ani nie potrzebował cytować starych tragedii ani uciekać się do imion sławnych od wieków; przeciwnie - jeśli mielibyśmy chęć go słuchać, on mógłby opowiedzieć historię, która przyszła mu do głowy. Potem, gdy my wszyscy zwróciliśmy ku niemu nasze twarze i uwagę, zaczął..." 30 Tu pojawia się typowa narracja intradiegetyczna o pewnej wdowie z Efezu. Jednak widać dobrze, jak w tekst z 1 os. pl. wpisano opowieść w 3 os., która nie ma istotnego znaczenia dla przebiegu podróży. Kiedy powraca narracja pierwszoosobowa, akcja posuwa się do przodu: dochodzi do rozbicia okrętu w czasie sztormu. Enkolpiusowi, Gitonowi i Eumolpusowi udaje się uratować docierają w okolice Krotony, gdzie mieszkają „łowcy spadków”. Eumolpus udaje bezdzietnego, schorowanego bogacza, a Enkolpius i Giton - jego niewolników. W Krotonie spotykają się z gościnnym przyjęciem przez mieszkańców.

Warto też zauważyć, że Petroniusz nie zdaje się na domyślność i erudycję odbiorców. Wprowadzając do narracji opis podróży, wyraźnie zaznacza, że nawiązuje do Homera nie tylko w treści, ale także w poetyckiej formie, która kontrastuje z dominującą w utworze prozą:

Opuść dom i szukaj obcych krain

Dzielny młodzieńcze; twoje przeznaczenie przyniesie ci więcej [...].

${ }^{28}$ M. Holzberg, Powieść antyczna, 74.

${ }^{29}$ Por. V.K. Robbins, The social Location of the implied Author of Luke-Acts, w: The social Word of Luke-Acts. Models for interpretation, red. J.H. Neyrey, Peabody 1991, 305-332.

${ }^{30} \mathrm{Za}$ : http://www.gutenberg.org/etext/5221 (27.03.2008). 


\begin{abstract}
Dunaj daleki
powinien znać twego ducha, i gwiazda polarna,

i Nil spokojny, i ci, którzy zamieszkują lądy,

gdzie słońce wstaje i gdzie zachodzi!

Nowy Ulisses stąpa po nieznanych piaskach ${ }^{31}$.
\end{abstract}

W późniejszym czasie, np. w tekstach Apulejusza (Metamorfozy - II w.) czy Heliodora (Opowieści etiopskie - III w.), nawiązania są bardziej subtelne i wyrafinowane.

Narracja pierwszoosobowa w periplusie ma jeszcze jeden cel, który ujawnia się zwłaszcza przy opisie burz, nawałnic, katastrof. W sposób znaczący wzmaga ona napięcie poprzez, jak już częściowo wspomniano, zastąpienie narratora autorytatywnego, wszechwiedzącego - narratorem uczestniczącym w wydarzeniach, aktorialnym. Pełne napięcia i dramatyzmu sceny rozgrywają się na oczach odbiorców, narrator widzi to samo, co oni, nie ulega pokusie wyjaśniania tła i/lub wszystkich związków pomiędzy poszczególnymi elementami i poziomami tekstu. Interpretację pozostawia autor wewnętrzny odbiorcom, zmusza ich przez to do refleksji.

Przyjęcie wspólnego punktu widzenia dla narratora i odbiorców można również rozpatrywać w kategoriach pragmatycznych. Nieprzypadkowo zapewne wspólny punkt widzenia zestawiono z periplusem. Motyw okrętu miotanego przez sztormy i jego alegoryczne znaczenie należały do popularnych toposów; wykorzystali go m.in. Horacy i Apulejusz. Skorzystał z niego również autor wewnętrzny Dziejów Apostolskich. Narracja pierwszoosobowa sprawia, że każdy z adresatów mógł utożsamić się z załogą statku, kolejne etapy morskich podróży postrzegać jako koleje własnego życia i nabrać przekonania, że wszystko, co go spotyka, dzieje się z woli Boga. Wtręty trzecioosobowe pokazują najbardziej pożądaną, wzorcową postawę, którą reprezentuje Paweł - bezwzględną ufność Bogu i wypełnianie powierzonej przez Boga misji.

Inaczej należy interpretować te fragmenty Dziejów, w których periplus nie zostaje zamknięty odpowiednią formułą, a bohaterowie nie opuszczają miejsca pobytu drogą morską, lecz udają się w głąb lądu $(21,15 c-17 ; 28,11-16)$. Przesuwanie się akcji w głąb lądu oznacza oddalanie się od konwencji periplusa i kierowanie się w stronę gatunku określonego przez uczonych renesansowych jako hodoeporikon, czyli opisu podróży prozą lub wierszem, spokrewnionego blisko z rzymskim itinerarium. W przeciwieństwie do epizodycznych narracji wplecionych w periplousy, te fragmenty są dla utworu znaczące, posuwają akcję do przodu, mają charakter o wiele bardziej historiograficzny niż fabularny.

\footnotetext{
${ }^{31}$ Tamże.
} 
Przy założeniu, że narracja pierwszoosobowa została celowo wprowadzona do utworu przez autora wewnętrznego i przy zastosowaniu kryteriów literackich przy jej interpretacji, widać, że wszystkie fragmenty z Wir-Berichte wpisują się w podobny schemat fabularny właściwy gatunkowi literackiemu zwanemu periplus. W tym wywodzonym z Odysei gatunku bardzo często stosowano narrację pierwszoosobową, zwłaszcza wtedy, gdy periplus stanowił komponent jakiegoś większego eklektycznego gatunkowo dzieła. Eklektyzm z kolei pozwalał autorowi i odbiorcom na podjęcie gry intertekstualnej. Ma to miejsce również w przypadku Dziejów Apostolskich - utworu, w którym dominuje zretoryzowana historiografia, ożywiana i uatrakcyjniana cudownymi epizodami, przypowieściami, mowami i morskimi opowieściami. Występowanie obok siebie narracji pierwszo- i trzecioosobowej jest nie tylko wynikiem zastosowania odpowiedniej konwencji. Służy również zaznaczeniu zmiany gatunku, uwrażliwieniu odbiorców, skłonieniu ich do refleksji poprzez przyjęcie wspólnego z narratorem punktu widzenia. Na tym tle narracja trzecioosobowa jest lepiej widoczna. Wpleciona w struktury „zamkniętych” periplusów ukazuje odbiorcom optymalną, wzorcową postawę życiową, pojawiająca się w sąsiedztwie periplusów otwartych - jest elementem rozwijającym akcję utworu. 


\section{Summary}

The Acts of the Apostles cointain the passages in the first person plural narration - 16,10-17; 20,5-15;21,1-18;27,1-28,16. The presence of this narration coincidences with a sea voyages. Sea journey appears often in Greek and Roman literature - so for example in Homer's Odyssey, in works of Alcaeus, Mimnermos, Vergil, Petronius, Lucian, Heliodor. One of the primary features of this genre - the so-called periplus - is the presence of first person plural narration; other features are: the beginning of the sailing, halting places of the journey, landing at the places, meeting with local inhabitants and resuming the voyage. The author of Luke-Acts employs his periplus with great skill and uses first person plural as the stylistic component of this genre.

However, the first person plural narration in the Acts makes often a transition to third person narration or to a speech. The third person narration and a speech within the "we-passage" are a kind of the excurses. The third person narration appears also in the episodes recounting Paul's overland travels; these episodes belong to the main action.

The usage of the first and the third person narration according to the generic convention suggests that the author of Luke-Acts is a versatile Hellenistic writer who is an intelligent participant in the literary arena of Mediterranean culture. 
